\title{
Culture-bound references through the prism of domestication and foreignization. A case study of the Arabic-English translation of the novel Dhakirat al jassad
}

\author{
Besma Boudhen ${ }^{1}$ \\ University of Algiers II Abou El Kacem Saadallah \\ Translation Institute $\cdot$ Rue Djamel El Dine EL-AFGHANI $\cdot$ Bouzareah $\cdot$ Algérie
}

ABSTRACT

This study sets out to investigate the concepts of domestication and foreignization introduced by Lawrence Venuti through examining the transfer of culture-bound references in the translation of the novel "Dhakirat al jassad ذذاكرة الجسد" (Memory in the Flesh) by the world's best-known Arab woman novelist, Ahlam Mosteghanemi. A translation that was carried out from Arabic into English by the Lebanese journalist and translator Baria Ahmar Sreihn.

The protagonists (khaled and Hayat) both come from the capital of Eastern Algeria: Constantine, which is also the author's hometown. Algeria, as the biggest country in Africa, is home to numerous cultures, dialects and even languages. Constantine is thus considered an Algerian cultural and civilization beacon that has its own culture, habits and customs which the Arab reader can feel through the extensive use of culture-bound references by Mosteghanemi. In addition to that, the reader can also feel the French influence in Mosteghanemi's style, an influence that can be explained by the fact that the French colonialism stayed in Algeria for over 132 years.

We selected 14 occurrences of culture-bound references to be analyzed and criticized from the first chapter of the novel. How did the translator deal with a different culture than hers? How did she render all of the Algerian culture-bound references in English? Were they adapted? Omitted? Or kept as they are? According to Lawrence Venuti, the translator should always choose to foreignize rather than domesticate. On another note, Schleirmacher speaks about two major things from which the translator chooses: "He either leaves the writer in peace as much as possible and moves the reader toward him; or he leaves the reader in peace as much as possible and moves the writer toward him." We therefore put forth the hypothesis that the translator domesticated all of the culturebound references in order to "move the writer (and her culture) toward the reader".

Keywords: literary translation - culture-bound references-domestication and foreignization.

\section{ABSTRACT}

La présente étude se propose d'investiguer les deux concepts de domestication et d'étrangéisation introduits par Lawrence Venuti. Nous allons en effet analyser le transfert des références culturelles dans la traduction du roman "Dhakirat al Jassad الجسا (Mémoires de la chaire) de la romancière arabophone la plus connue du monde : Ahlam Mosteghanemi. Une traduction qui a été faite de l'arabe vers l'anglais par la journaliste et traductrice libanaise Baria Ahmar Sreihn.

Les protagonistes (Khaled et Hayate) sont tous deux natifs de la capitale de l'Est algérien : Constantine, la ville natale de l'auteure. L'Algérie est, en effet, le plus grand pays d'Afrique. Par conséquent, il jouit d'une immense diversité culturelle, dialectale et même linguistique. Constantine est, donc, considérée comme l'un des flambeaux culturels et Friedrich, (els de ce pays. Ayant sa propre culture, habits traditionnels et coutumes, Constantine est présentée au lecteur Arabe grâce à l'utilisation extensive des références culturelles par Mosteghanemi. De plus, l'influence de la langue française peut aussi être perçue dans le style de Mosteghanemi. Une influence qui se justifie par les 132 années de présence coloniale française sur les territoires algériens.

Nous avons sélectionné 14 cas de références culturelles du premier chapitre du roman, et ce, aux fins de les analyser et les critiquer. Comment la traductrice a-t-elle abordé une culture si différente de la sienne ? comment a-t-elle rendu toutes les références culturelles 
algériennes en anglais? ont-elles été adaptées? omises ? ou gardées telles quelles ? Selon Lawrence Venuti, le traducteur doit toujours choisir d'étrangéiser au lieu de domestiquer. Shleiermacher, lui, parle de deux choix auxquels le traducteur fait face : il doit soit « choisir de laisser l'auteur en paix le plus possible et emmener le lecteur à sa rencontre ou bien laisser le lecteur en paix le plus possible et emmener l'auteur à sa rencontre ». De ce fait, nous avons émis l'hypothèse que la traductrice a domestiqué toutes les références culturelles afin d' « emmener l'auteure (et sa culture) à la rencontre du lecteur ».

\section{Introduction}

Since culture-bound references CBR (also referred to as cultural references) are an integral part of any culture, knowing them allows for an efficient cultural exchange and understanding between nations. The Quran, which is the first reference in the Arab culture, calls for intercultural exchange and stresses how important it is for the humans to know one another:

[ And among His Signs is the creation of the heavens and the earth, and the difference of your languages and colours. Verily, in that are indeed signs for men of sound knowledge. ] (Quran chapter (30) sūrat 22 translation of Mohsin Khan).

And in another verse:

[O mankind! We have created you from a male and a female, and made you into nations and tribes, that you may know one another. ] (Quran Chapter (49) surat 1 Translation of Mohsin Khan)

The cultural dialog between Arabic and other European languages has known some ups and downs. Translation from Arabic is not always initiated for the good reasons. In fact, Büchler and Guthrie (2011, p. 7) prove it through their series of reports on literary exchange, translation and publishing where they state that there was, in fact, a very important translation movement from Arabic into European languages in the Abbasid Era (750-1258) and also in Al Andalus; mainly in Granada and Cordoba, where the culture of international exchange knew its golden age. However, after the fall of $\mathrm{Al}$ Andalus things began to change for the worse as translation from Arabic into other languages began to know a decline which happened mainly as a result of the widespread suppression of the Arabic culture in Europe. The situation began to change in the $18^{\text {th }}$ and $19^{\text {th }}$ centuries, following the European colonial involvement in certain Arab countries. This prompted the emergence of some English translations of the holy Quran, poetry and books such as “The Thousand and One Nights”. Unfortunately, once again this slight shift in the translational movement from Arabic to other languages was motivated by orientalist interest rather than pure literary appreciation according to Büchler and Guthrie. (ibid., 2011, p. 7)

This short retrospective view on the translation movement from Arabic to European languages -especially English- allows us to evaluate the current situation within its general context including the past which led to the present in order to anticipate the future and identify the points that may cause problems in this area. At present, the same problem persists as translations published from Arabic are still not enough. In fact, the same report concluded that publishers" interest in books coming from the Arab world is determined by "extra literary factors" such as the 9/11 attacks, which shed light on anything Arab, once again for the wrong reasons. This means that socio-political factors are mainly behind the publishers' interest in books coming from the Arab world rather than the desire to explore its literature. This is mainly why almost exclusively specialized publishers are the ones who take an interest in translation from Arabic. (Büchler and Guthrie, 2011, p. 7)

What we understand from this report is that culture seems to come at the very last position in translating and publishing Arab literature. Thus, the cultures of the Arab world at large remain unknown. It is commonly known 
that ignorance generates fear and fear generates hate, whereas translation can mend misunderstandings and bridge the gaps and differences between people. This is what Lawrence Venuti advocates:

[A strategic use of minority elements can remain intelligible to a wide range of readers and so increase the possibility that the translation will cross the boundaries between cultural constituencies, even if it comes to signify different meanings in different groups.] (Venuti, 1998, p. 12)

In fact, Venuti thinks that translators should foreignize rather than domesticate foreign literary works in order to keep their culture intact. How can we know a particular people if we always domesticate their literature? This is what sparked my interest in this topic and prompted my to try to find out how the extensive use of Algerian CBRs in the best seller novel Dhakirat al-Jassad ذاكرة الجسد (Memory in the Flesh) by Ahlam Mosteghanemi were transferred in its English translation;

- How did the translator deal with a completely different culture than hers?

- How did she render all the Algerian CBRs in English?

- Were they adapted? Omitted? Or kept as they are?

A hypothesis was therefore put forth: the translator may have domesticated all the CBRs in order to "move the writer (and her culture) towards the reader" in the words of Schleirmacher (1813).

\section{Culture-bound references in literature}

Newmark (1988, p. 94) defines culture as:

[the way of life and its manifestations that are peculiar to a community that uses a particular language as its means of expression]

In order to translate a literary work, the translator not only has to master both the source language and the target language but they also have to learn about the author's background in order to know where their writing style comes from. In fact, language differences are nothing but the tip of the iceberg according to Guidère (2011, p. 142). He thinks that the biggest challenge for the literary translator is rather the mediation of cultural differences.

The style of a novelist reflects their life experience and mirrors their general background. Therefore, by using CBRs, the author asserts their identity and openheartedly speaks to the reader by referring to things from their childhood and memory: dishes their mother used to cook them and places where they used to spend time... this is what Lecercle (1990) calls the "reminder". In addition to the mere stylistic aspect or the author's self-assertion, culture-bound references can also be an effective tool to give a fictional character more dimension and complexity.

Human beings are created different; therefore, they see the world from different perspectives; what may seem strange to one, may seem normal to another and vice versa. Eventually what used to seem strange in a certain area of the world will grow to be familiar through the translation of culture and by avoiding its domestication.

[Before, much of the writing about other peoples was simply a collection of unexplained exotica: shocking rituals, strange practices, irrational behaviour of creatures not fully human. Since Evans-Pritchard there has been a concerted attempt to understand these same rituals, practices, and behaviour in such a way as to grasp the human experience, to see the human problems and perplexities, to reduce the false exoticism that prevents us from understanding people who are fundamentally like ourselves, but whose lives are shaped - both facilitated and constrained - by circumstances different from ours.] (Marshall Morris, in: Anderman and Rogers, 2003, p. 89) 
The anthropologist Evans Prichard coined the term "translation of culture" (Beidelman, 1971). He argues that every people on this planet should have the chance to be understood without domesticating or transforming the way they see and describe the world (Marshall Morris, in: Anderman and Rogers, 2003, p. 88). One great misconception about the Arab world is that it is home to one people sharing one same language, culture and religion. Astonishingly, when we speak about the Arab world, there is a particular image that directly comes to mind: men in white Qamis and women in black Niqabs, camels, desert and a particularly strong accent. However, not all Arab countries are historically Arab. Every country has its own blend of cultures which makes it what it is today. In this respect, Algeria is no exception to this. It is home to several cultures, languages, dialects and accents. In fact, the multiple foreign invasions to which the country was confronted throughout history yielded a cultural and linguistic hybridity in each and every corner of present-day Algeria: from the Phoenicians to the Romans, Vandals, Byzantines, Arabs, Spaniards, Turks and finally the French, whose occupation ended in 1962. All these invaders left their fingerprints that are still visible today alongside those of its original people: the Amazighs $^{2}$. Venuti points out that some writers take this heterogeneity generated by all these influences as one of their strengths:

[Certain literary texts increase this radical heterogeneity by submitting the major language to constant variation, forcing it to become minor, delegitimizing, deteriorating, alienating it.] (Venuti, 1998, p. 10)

While scholars such as Vinay and Darbelnet (1977) have introduced one of the leading taxonomies of translation procedures based on comparative stylistics, some other studies focus specifically on cultural translation procedures: Grardler (2010), Harvey (2000), Duenas (2003), Brillo (2004) but also Newmark (1998, p. 103). The latter suggests twelve strategies which allow the literary translator to deal with the cultural gap that exists between ST and TT, namely:

- Transference: this translation procedure includes transliteration which is the transfer of a word from a different alphabetical system (Chinese, Arabic, Greek...) into the target text (Newmark, 1988, p. 81-92). Vinay and Darbelnet call it: borrowing;

- Cultural equivalent: a cultural equivalent is the translation of a cultural word by an approximate cultural equivalent in the target culture;

- Neutralization: functional or descriptive equivalent;

- Literal translation: he also calls it "through-translation" which consists of a direct and literal translation -as its name suggests- of common words and collocations;

- Translation label: it is the provisional translation of a new institutional term -made in inverted commas- which can be withdrawn later;

- Naturalization: it is the adaptation of a SL word first to the pronunciation then to the normal morphology of TL;

- Componential analysis: it consists of splitting up a lexical unit into its sense components;

- Deletion: suppression of redundant stretches of language in non-authoritative texts, especially metaphors and intensifiers (Vinay and Darbelnet call it: omission);

- Couplets: this procedure consists of matching two or more procedures to deal with one single problem;

- Accepted standard translation: it is the official recognized translation for a particular institutional term to which the

The Amazighs are the indigenous people of North Africa. 
translator may or may not adhere;

- Paraphrase, gloss, notes, etc: this translation procedure consists of explaining and amplifying the meaning of a given cultural word;

- Classifier: it is the explicitation of implicit information that the target readership ignores. Newmark gives an example for it: [Speyer becomes "the city of Speyer."].

Peter Newmark (1998, p. 96) argues that translators have to bear in mind two main considerations when translating cultural words; first, to show respect to all foreign cultures which can be achieved through two translation procedures: either transference or componential analysis. The first preserves the culture but blocks the message from getting across, while the latter -although not economical and does not have the pragmatic impact of the original- does the opposite. The second consideration that Newmark points to is the fact that the translator of cultural words has to pay attention to the motivation and the cultural specialist as well as the linguistic level of the readership. He also divides cultural words into five main categories (Newmark, 1998, p. 95):

- Ecology: which includes fauna, flora, hills, winds, plains...;

- Material culture: which includes food, clothes, houses and towns, transport...;

- Social culture: including work and leisure;

- Organizations, customs, activities, procedures, concepts: which can be either: Political and administrative, but also religious or artistic;

- Gestures and habits.

\section{Venuti's domestication and foreignization}

Domestication and foreignization are two terms coined by Venuti to describe two major trends in literary translation. The first strategy, domestication, aims to minimize the otherness of the foreign text. Venuti defines it as:

[an ethnocentric reduction of the foreign text to target-language cultural values, bring the author back home] (Venuti, 1995, p. 145)

Whereas the Dictionary of Translation Studies describes it as:

[a strategy that is adopted in order to minimize the strangeness of the foreign text to TL readers] (Shuttleworth \& Cowie, 2014, p. 43-44).

Foreignization, on the other hand, does the opposite. It is a strategy that aims to preserve the otherness and allows the reader to discover a new world different than theirs. Venuti defines it as:

[an ethnodeviant pressure on those (cultural) values to register the linguistic and cultural difference of the foreign text, sending the reader abroad.] (Venuti, 1995, p. 20).

And according to the same source, foreignization:

[designates the type of translation in which a TT is produced which deliberately breaks target conventions by retaining something of the foreignness of the original.] (ibid., 1995, p. 20). 
The practice of these two translation strategies has always existed especially domestication which was largely used by Latin translators in ancient Rome. Schleiermacher was a precursor in speaking about this practice in 1838 through his famous notion of "either leaving the reader in peace as much as possible and moving the author towards him or leaving the author in peace as much as possible and moving the reader towards him" (Schleiermacher, 1813). But Venuti's invaluable contribution made it possible to transpose this ever-existing author-reader relation (in which the translator's role is decisive) to today's translation reality. In fact, He does not look favorably on domestication. As an American researcher, he made a critical analysis of the translation system in the Anglo-American context. He found that his culture was mainly ethnocentric; as it always sanitizes foreign literary works by erasing their strangeness and assimilating them to itself. These cultures are according to him:

[accustomed to fluent translations that invisibly inscribe foreign texts with (target language) values and provide readers with the narcissistic experience of recognizing their own culture in a cultural other] (Venuti, 1995, p.15 in: Shuttleworth \& Cowie, 2014, p. 44),

He also described these dominant cultures as:

[aggressively monolingual, unreceptive to the foreign] (Venuti, 1995, p. 15 in: Ibid, 2014: 44).

This domesticating approach to translation calls for a series of text manipulation techniques that remind us somehow of Berman's twelve deforming tendencies which prevent the foreignness of the source text from appearing in the target text: rationalization, clarification, expansion, ennoblement, qualitative impoverishment, quantitative impoverishment, the destruction of rhythms, the destruction of underlying networks of signification, the destruction of linguistic patternings, the destruction of vernacular networks or their exoticization, the destruction of expressions and idioms, the effacement of the superimposition of languages (Berman, 2000).

\section{Methodology and corpus presentation}

In order to investigate the translation of culture bound references in the novel dhakirat al-Jassad, forteen occurrences of culture-bound references from the first chapter of the novel were selected to be analyzed alongside their respective translations and each translation will be criticized. Thus, this section presents:

- A short background information about the author Ahlam Mosteghanemi,

- A synopsis of the corpus Dhakirat al-jassad where I will speak about the place that the author's country Algeria and her hometown Constantine occupy in her novel.

- The functional aspect of the novel.

- A short presentation of its English translation: "Memory in the Flesh".

\subsection{About Ahlam Mosteghanemi}

[Cette écrivaine algérienne, grande sentimentale mais aussi clairvoyante, est la plus lue du monde arabe.] (Catherine Schwaab, Paris Match, 2018)

$$
\text { i.e. }
$$


[This Algerian writer, who is a great sentimentalist but also farsighted, is the most read in the Arab world] (my translation)

Ahlam Mosteghanemi is an Algerian novelist from the city of Constantine, the capital of Eastern Algeria. She was born in Tunis after her father -then a freedom fighter against the French colonialism- was forced into exile to Tunisia with his family during the Algerian Liberation War. While in Tunis, Ahlam's father, the French speaking Mohamed El Cherif decided to give his daughter what he could not get back home, namely an Arab education allowing her to learn Modern Standard Arabic (MSA). The teaching of latter was banned under the French colonialism. In fact, MSA is the formal language used in literature, Quran, schools and education in general. It is common to all Arab countries, while the Darja or Algerian dialect is only used by Algerians in everyday life and is, thus, a carrier of their culture and identity. These multiple influences are mainly the reason why Ahlam has a triple culture that the reader can feel through her writing style: a default French culture that she acquired at home from her father and an Arabic culture she acquired from school. Not to mention her local Algerian culture which constitutes an integral part of her. In fact, she is a lover of her culture and makes sure to appear proudly wearing traditional dresses from all over Algeria on official events. She also makes sure to either write about Algeria or to refer to it in each one of her novels.

As soon as Algeria regained its independence in 1962, Mosteghanemi's family moved back to dear homeland, where Ahlam's father Mohamed El Cherif eventually takes up a senior position in the first Algerian Government. Ahlam, then, pursues her studies at the University of Algiers where she graduates with a bachelor's degree in Arabic literature. Her controversial freedom of speech prevented her from pursuing her studies to get higher degrees. In fact, the board of Directors of the University of Algiers refused her enrolment for a master's degree under the pretense that she had a negative impact on students. After meeting her future husband in Algiers, a Lebanese journalist and historian, the couple moved to Paris where Ahlam continued her studies at the Sorbonne obtaining a doctorate in sociology. (Mosteghanemi’s biography, www.ahlammosteghanemi.com)

\subsection{Corpus presentation Dhakirat El Jassad:}

While in France, Mosteghanemi made several contributions in various magazines and writes her first novel Dhakirat El Jassad. She then settles down in Lebanon where she presents her novel to the editor of the famous publishing house Dar El Adab, who was amazed by it. The novel, written in a highly poetic style and bearing political views and issues, is a revelation, and will have a phenomenal success throughout the Arab world. (Mosteghanemi's biography, www.ahlammosteghanemi.com)

$$
\begin{aligned}
& \text { "....هذه الرواية لا تختصر ذاكرة الجسد فحسب، ولكنها تختصر ذاكرة الوجع الجزائري، والحزن الجزائري، والجاهلية الجزائرية التي آن لها أن } \\
& \text { تنتهي..." (نزار قباني) } \\
& \text { i.e. }
\end{aligned}
$$

[...Not only does this novel summarize the memory of the flesh but it also summarizes the memory of Algerian pain, Algerian grief, and Algerian ignorance that is ought to come to an end...] Nizar Kebbani (my translation)

The love story in Dhakirat El Jassad is set between an armless painter and the daughter of his former commander encountered in Paris 25 years after the war. The novel evokes the disappointment of the post-war generation, which echoes the disappointment of a generation of Arabs. In a famous letter to the author, Nizar Kabbani, the great contemporary Arab poet, declared: [This novel gave me vertigo; had I been asked, I would have signed it]. The director Youssef Chahine, winner of the Palme d'Or, purchases the rights to the film shortly before his death. 
Meanwhile, the famous Hollywood director Mustafa Akkad said that one of his dreams was to adapt Dhakirat el Jassad into a movie. Moved by his reading, the former Algerian President Ben Bella will say from his exile: [Ahlam is an Algerian sun that illuminates the Arab world]. To date, more than one million copies have been sold across the Arabic-speaking world (excluding pirated editions which vastly outnumber the legal editions in the Arab world). This novel also has the merit to reconcile the Arab reader with the Arabic language and reading. (Mosteghanemi's biography, ibid.)

\subsubsection{Synopsis of the novel}

Khaled, the protagonist and narrator of the story, is a former Algerian freedom fighter who lost his left arm during the Algerian war against France in the 1940's. He meets Hayat, the daughter of Si Tahar, a revolutionary leader he met at the age of sixteen. After khaled's mother passed away, he tries to find comfort in the arms of his motherland Algeria for whom he fought until two bullets forced him to leave the battlefield and go receive medical care in the neighbouring country, Tunisia. However, before leaving, Si Tahar asks Khaled to visit his family in Tunis and register Si Tahar's new-born daughter, giving her the name Hayat, which he did. Si Tahar later dies in the wake of independence.

20 years later, Khaled and Hayat finally meet and fall in love despite the age difference, Khaled was captivated by the traditional bracelet she was wearing as it reminded him of his hometown Constantine. He saw in Hayat old Algeria and the authenticity of Constantine. However, he soon realizes that Hayat is not that authentic. In fact, he discovers in her this post-colonial Algeria with different values, shallowness, materialism and western influence. This novel tells Algeria's past and present, it is concerned with Algeria's struggle against foreign domination as well as its post-independence struggle with itself and the fate of revolutionary ideals in a postrevolutionary society.

\subsubsection{The functional aspect of the novel}

Every novel is written for a purpose, be it a hidden or a declared one. Ahlam's novel is no exception to this; it was written first and foremost to entertain the readership, who is given the opportunity to appreciate the Algerian literature, a literature that bears a myriad of colors and influences coming from different horizons that nurtured Ahlam like it did with every other Algerian writer. Among these influences is the French culture that she did not choose, but rather forced its way into her style.

Through this novel, Ahlam is also sending a postcard of her country, Algeria and her hometown, Constantine. By doing so, she opens her doors to the Arab world to have a taste of the Algerian coffee, walk through the streets of Constantine, hear the Algerian dialect line after line (every now and then to break the academic stiff aspect of Modern Standard Arabic) and get familiar with how it sounds, putting the readership into the authentic true context of the story that happens in the heart of Algeria. This is why the presence of code switching between modern standard Arabic MSA and dialectal Algerian can be noticed in addition to the cultural specificities such as certain concepts and notions that only Algerians are familiar with. Although, through writing about them, Ahlam is also introducing them to the Arabs who quite generally ignore this part of Africa that is the Maghreb. Last but not least, Mosteghanemi's true goal behind her novel is to talk about the Algerian revolution, her pride 
and joy, the struggle of one single hero: the people. She wanted to honor the freedom-fighters who sacrificed their lives for the sake of this nation, and to make an observation 25 years after independence, by comparing old Algeria (Khaled) and present-day Algeria (Hayat); now that Algeria is free, is it still keeping its values and ideals or had it deviated from them?

It would be necessary to know if the translation respected the same goals set by the writer of the original, did the translator succeed in translating and conveying the same intentions aesthetically and informatively or had the translation deviated from its skopos? Friedrich Chleiermacher thinks that the translator can either chose to leave the writer in peace as much as possible and moves the reader toward him; or to leave the reader in peace as much as possible and moves the writer toward him, was the translator source-oriented or was she target- oriented? We will see which of these two orientations the translator took.

\subsubsection{The translation Memory in the Flesh}

Dhakirat Al Jassad was translated by Baria Ahmar Sreih from the American University in Cairo and revised by Peter Clark in 2000, under the title of "Memory in the Flesh". The translator, Baria Ahmar Sreih, is a Lebanese journalist and translator who lives in Canada. The latter also translated Mosteghanemi's Chaos of the senses from Arabic into English in 2004.

A re-translation of the book by Raphael Cohen has been published in a new edition under the title of Bridges of Constantine by Bloomsbury Publishing. Mosteghanemi mentioned in an interview to the journal Women: $a$ cultural review that the first translation, entitled memory in the flesh, did not reflect the work's literary sensibility (Nuha Baaqeel, 2015: 146).

[These readers can sense and understand that there is something missing in the translation. ]

We will see how Baria translated the novel through the analysis.

\section{Data Analysis}

This critical analysis aims to highlight the Algerian specificities -specifically words and sentences expressed in Algerian Darja- in the original novel, more precisely in the first chapter alongside their English translations. We will explain each culture-bound reference, compare the original and the translation and describe the translator's choices: why did she make certain choices instead of others? Did she have the choice or was she confronted with inevitable decisions? I classified the selected cultural references into six categories: adapted culture-bound references, deleted culture-bound references, code switching, mistranslated culture-bound references, explicitated culture-bound references and finally the French influence in Ahlam's writing. In each case, two to three examples will be analyzed.

\subsection{Adapted culture-bound references}

$$
\text { وتعجنين تلك الكسرة back translation: "You are kneading that Kesra" }
$$


This sentence was translated as: "Making bread". Kesra is the name of a traditional Algerian flat bread made with semolina, oil, salt and water then baked on a special utensil called the "tajine". Kesra is therefore not any bread, it is a specific kind of bread commonly known in Algeria only. Kersa was translated as bread, a move from specific to general can be notice (hyponymy). This happened through the adaptation of this very particular kind of bread using a general term known to all. This shift, according to Newmark's translation procedures, is a functional equivalent. gack translation: "stretching out to Constantine, clad in its old M'laya"

This sentence was translated as "Covered with its old veil". Here, the author is talking about the M'layas الملاية, a black large piece of clothing characteristic of the city of Constantine (not even to other Algerian cities). This Constantinian clothing used to be worn white but soon women started wearing black M'layas as a sign of mourning when the very popular Governor Salah Bey of Constantine passed away in 1792. In this respect, the M'laya is not just any veil. As a matter of fact, a veil only covers the head, whereas the M'laya is a large piece of fabric which covers all the body. This piece of clothing is folded into several parts and worn in a specific manner. The translator's adaptation of this word into "veil" makes it too general.

\subsection{Omitted culture-bound references}

$$
\text { back translation: “a mrach of orange blosom water" }
$$

This sentence was translated as «Orange flower water». The omission of "mrach" can be noticed here. A mrach is an Algerian ustensil, made from either silver or copper bearing orange blossom water or rose water and generally served with coffee to flavor it. The translator did not translate this item. She preferred to translate the content and deleted the container because the latter does not exist in the western culture. This omission is a deletion according to Newmark.

$$
\text { back translation: "How could I have imagined you wearing her Annabi dress" }
$$

This sentence was translated as "How could I have imagined you wearing her dress". The word Annabi can mean two things in Algerian Darja. It is either a reference to Annaba which is a city not very far from Constantine, Annabi in this case would mean: the dress from the city of Annaba. Another meaning of this word can be the garnet color which is called Annabi in Algerian Darja. Here the translator decided once again to omit the culture-bound reference and to translate it as dress. This would mean that this Annabi dress is like any other dress. This, again, is deletion according to Newmark and it obliterates the specific origin of a cultural item.

\subsection{Code switching}

$$
\text { gack translation: “and for m’ma, whom he knew very well”" }
$$

This sentence was translated as "And for my mother, whom he knew very well”. In Algeria, there are too many ways of saying the word "mother" one of them being Yemma in the west and in the Center, and m'ma in the east, especially in Constantine. The formal MSA version of this word is "oummi" meaning mother while m'ma is more intimate and rather means mum. The translator chose to obliterate the code switching between formal 
and informal language following a target-oriented macrostrategy. This code switching resulted in a neutralization.

$$
\text { back translation: "hello Si Khaled, wesh rak elyoum” }
$$

This sentence was translated as "Hello, Si Khalid, how are you today?". this sentence bears more than one culture-bound reference. First, the word $\mathbf{S i}$ is used in Algeria as a polite form. The equivalent in MSA is the word "Sayyidi" which literally means Sir. But the MSA Arabic Sayyidi is more formal and rigid than the Algerian "Si". Here the translator kept the lexical unit "Si" as it is, translating it "Si Khalid" in English, which is a transference according to Newmark. In fact, she kept this foreign word hoping that it would be understood from the context. However, she could not keep all the Algerian specific items in the sentence. In fact, "wesh rak elyoum" means "how are you today?" in Darja and cannot be understood by an English-speaking readership. Thus, it was simply translated.

$$
\text { back translation: “O apple, O apple... why people adore you. }
$$

This sentence was "translated as $\mathrm{O}$ apple, o apple... tell me why people adore you". At first glance, the translation is exact, and the rendering is direct. However, the reception of this sentence will differ from an Algerian readership to another. In fact, Algerians will know that these are the lyrics of a song by a very famous Algerian singer called Rabah Deriassa. The song evokes the music and the rhythm in the spirit of the readers who know it, although the translator cannot know that the song exists, it could be coming from the writer's incredibly wide imagination. So, the translator translated the meaning of the words not knowing that it is a song.

\subsection{Mistranslated Culture-bound references}

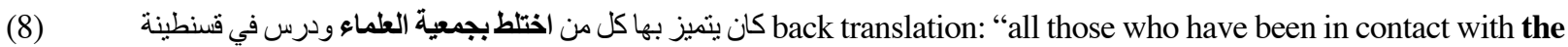
Association of Algerian Muslim Ulema” and studied in Constantine"

This sentence was translated as "All those who went to Islamic societies and studied in Constantine". Here, the Association of Algerian Muslim Ulema refers to the association of muslim intellectuals who fought the French during the French colonialism using knowledge rather than arms through establishing Free schools, teaching and spreading knowledge in Arabic among the Indegenous population. However, here, we notice that it was translated as "Islamic societies", which is incorrect.

$$
\text { الفلاقة back translation: "Al felaga" }
$$

This word was translated as "troublemakers". The literal meaning of the word Felaga is "bandit". In fact, it is a north african word: Algerian and Tunisian. The Frensh used it to refer to groups of armed Algerian nationalists who adopted armed resistance in order to push the French out of $\underline{\text { Algeria }}^{3}$. This word had a pejorative meaning in Algerian Arabic, which explains why the French adopted it at the time as a strategy to discourage and ridicule the resistants by calling them felagas. But to the Algerians, the Felagas were regarded as freedom-fighters, not troublemakers. Thus the word took on a positive meaning throughout the years. In this

http://en.wikipedia.org/wiki/Fellagha 
translation however, the first pejorative meaning was kept, it was translated literally as "troublemakers" without paying attention to what it evokes in the Algerian collective memory as it was used during a precise period of Algeria's History. Thus, the word "troublemakers" does not serve this aspect in the target text.

$$
\text { حينا بسيدي الكبروك back translation: "our neighborhood Sidi Mabrouk” }
$$

This sentence was translated as "Our neighboorhood in Sidi al-Mabruk". Here, we are dealing with a lexical mistake made in the original version itself. As a domino effect, it had its repercussions on the translated text as it reproduced the same mistake. the mistake that was made by the author is the "al" in "Sidi al-Mabruk". The correct name of this famous neighbourhood situated in the plateau of Al Mansurah in Djebel El Wahch area of Constantine is "Sidi Mabrouk". The translator, however, introduced the definite article "al" into it. this shows that the translator is naturally drifted away by the mistakes encountered in the original, especially when it comes to cultural references.

\subsection{Explicitated culture - bound references}

$$
\text { back translation: “and the motherland rubs off on my hands like black ink" }
$$

This sentence was translated as "And the black ink of Algeria rubs off on my hands" here Ahlam did not precise which country she is talking about, the reader can understand that she is speaking about her country Algeria without literally saying it explicitly. However, the translator preferred it to be more obvious, this is why this information was explicitated in the target text: "Algeria", which is a classifier according to Newmark's taxonomy.

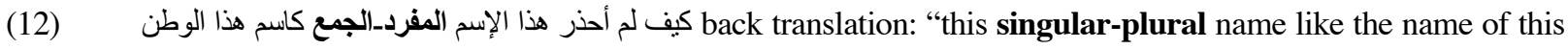
country"

This sentence was translated as "a name that was both singular and plural, like the name of this nationAlgeria, al-Jaza'ir, meaning islands". In order to understand what the author meant by this, we need to go back to the etymology of the word Al-Jaza'ir (the Arabic name of Algeria). This word means islands and the name of the protagonist, Hayat, means "life" in Arabic. The writer establishes a parallel between two names that both bear plural form and singular form at the same time yet both represent one single thing: a country and a girl. The problem of translating this comparison resides in the fact that the plural/singular aspect of Hayat and Algeria is only noticeable in Arabic. Thus the translator had no choice but to add extra information as an explanation of the Arabic plural/singular particularity that the name Al-Jaza'ir bears by saying "a name that was both singular and plural, like the name of this nation- Algeria, al-Jaza'ir, meaning islands", this can be seen as an addition (see Newmark's taxonomy above).

\subsection{The French influence in Ahlam's writing}

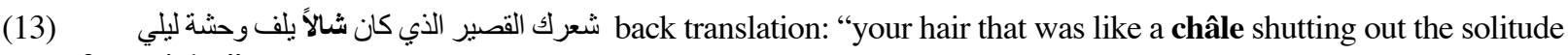
of my nights"

This sentence was translated as "Your hair used to be like a scarf that was so long it shut out the solitude of my nights" the French influence in Ahlam's writing is crystal clear and is perceived through the lexical items chosen 
to express concepts that, although they exist in Arabic, she chooses to borrow them from French. Here the word شال trademark. The word itself is a borrowing from French in the original text. However, it does not appear in the translation as it was rendered by the word «scarf » drifting the word to its « normal » state.

$$
\text { "Soirs, soirs. Que de soirs pour un seul matin » Henry Michou }
$$

This citation was reproduced in French by the translator before translating it into English : «Evenings, evenings, so many evenings for a single morning" here is an example of intertextuality of a French text into an Arabic one, the author is influenced by its readings in the French language, and of French writers, this influence is noticeable in the translation as well, the translator did not put the translated citation in English directly, but rather put it in French first then translated it into English.

\section{To conclude}

By way of conclusion, Dhakirat Al Jassad is a crossbreeding novel in which code switching between MSA and Algerian Darja is excessively used to place the reader in the true context of the Algerian society and as a feature of self assertion of Ahlam Mosteghanemi. As a matter of fact, through this novel, Mosteghanemi takes back her Algerian identity. An identity that was long fought by the French colonialism which claimed that Algeria was simply an extension of the French territory and that the French culture must prevail over it.

Dhakirat Al Jassad is a metis work of literature. Semantically speaking, the translation Memory in the Flesh was very pertinent and close to the original, many examples of faithfulness can be found in the ideas and layers of the story itself (the translator did not add or omit any idea, the story did not change in any case)

Nevertheless, far from central ideas and the story itself, the translation was characterized by adaptation moving the culture-bound reference from specific to general to make it easy for the target reader to understand. Also, classifier was used to simplify certain concepts. Berman considers it to be one of the twelve deforming tendencies as he argues that explicitating what the author purposefully made implicit will distort the literary work, and in this case the Algerian specificities were misrepresented. On another note, some other culture-bound references were completely deleted, and others were even mistranslated. The fact that the translator is Lebanese may explain the latter. In other words, the translation was characterized by transference rather than componential analysis.

Therefore, we can conclude that the translator privileged the understanding of the readership over the authenticity of the original work, as she adopted target-oriented strategies; she domesticated the novel in order to be easily apprehended by foreign readers at the expense of the author's trade mark, spirit, originality and especially Algerianity of her work. But in the light of all what we said about Baria's translation, one question comes to mind: were these domestication strategies the translator's choice? Did the editor impose certain choices to reach a bigger readership? Did her translation undergo changes by proofreaders, or by the publishing house? Unfortunately, all of these questions remain unanswered. But they do raise an important matter: Is the translator always the only one to put in the accused dock? Is the translator the only link in the translational chain? Thus, we have some reservations regarding who made these choices. However, we suggest that adding foot notes explaining the ambiguous notions and concepts was one possible option that could be implemented in order to keep the culture-bound references intact while explaining them at the end of the page. 


\section{About the author}

Besma Boudhene got her bachelor's degree in translation (French-Arabic-English) in 2012 from the Department of Translation at the University of Mentouri- Constantine, Algeria. After that, she pursued a master's degree in translation (English-Arabic-English) at the Institute of Translation and InterpretingUniversity of Algiers II, where she graduated top of her class in 2015. She, then, was ranked first in the national competitive exam for access to the $\mathrm{PhD}$ program in the same year. Currently, she is pursuing a $\mathrm{PhD}$ in Modern Translation Approaches at the Institute of Translation and Interpreting- University of Algiers II. She worked as a legal translator and a university teacher of French, English and research methodology in different university departments of her hometown, Constantine. She participated in several translation conferences both nationally and internationally and has several publications. Her research interests are: translation studies, audiovisual translation, subtitling, but also cultural studies and semiotics..

\section{References}

Adab, B. (2000). Evaluating translation competence. In C. Schaffner \& B. Adab (Eds.), Developing translation competence (pp.215229). Amsterdam: John Benjamins.

Anderman, G \& Rogers, M. (2000). Translator training between academia and profession: A European perspective. In C. Schaffner \& B. Adab (Eds.), Developing translation competence (pp.63-76). Amsterdam: John Benjamins.

Badan Pusat Statistik. (2018). Proporsi Penduduk Berumur 10 Tahun ke Atas yang Membaca Selama Seminggu Terakhir Menurut Provinsi, Jenis Bacaan, dan Tipe Daerah. <https:/www.bps.go.id/statictable/2014/08/20/1521/proporsi-penduduk-berumur-10tahun-ke-atas-yang-membaca-selama-seminggu-terakhir-enurut-provinsi-jenis-bacaan-dan-tipe-daerah-2012.html> [12/07/2018].

Beeby, A. (2000). Evaluating the development of translation competence. In C. Schaffner \& B. Adab (Eds.), Developing translation competence (pp.185-198). Amsterdam: John Benjamins.

Bernardini, S. (2004). The theory behind the practice: Translation training or translator education? In K Malmkjaer (Ed.), Translation in Undergraduate degree programmes (pp. 17-30). Amsterdam: John Benjamins.

Chipper, S. (2002). Business translation. Perspectives: Studies in Translatology, 10(3), 215-233.

Elthes, A. (2000). Reflection on teaching translation from French into Hungarian at the Technical University of Budapest: Towards a function-dependent course typology. In C. Schaffner \& B. Adab (Eds.), Developing translation competence (pp.101-114). Amsterdam: John Benjamins.

Gile, D. (2009). Basic concepts and models for interpreter and translator training. Amsterdam: John Benjamins.

Heidari, E \& Mowlaie, M. (2016). Iranian instructors' practices and criteria for teaching English translation. Theory and Practice in Language Studies, 6(3), 621-630.

Lauder, A. (2010). The Status and Function of English in Indonesian: A Review of Key Factors. Makara, 12(1), 9-20.

Lembaga Ilmu Pengetahuan Indonesia. (2015) Masyarakat kurang paham Iptek. <http://lipi.go.id/berita/single/Masyarakat-KurangPaham-Iptek/11040> [10/12/2018].

Kelly, D. (2000). Text Selection for Developing Translator Competence: Why Texts From The Tourist Sector Constitute Suitable Material. In C. Schaffner \& B. Adab (Eds.), Developing Translation Competence (pp.157-170). Amsterdam: John Benjamins.

Machali, R. (2009). Pedoman bagi penerjemah: Panduan lengkap bagi Anda yang ingin menjadi penerjemah. Bandung: Kaifa. 
MacKenzie, R. (2004). The competencies required by the translator's roles as a professional. In K Malmkjaer (Ed.), Translation in Undergraduate degree programmes (pp. 31-38). Amsterdam: John Benjamins.

Maia, B. (2010). The role of translation theory in the teaching of general and non-literary translation-revisited. In B. LewandowskaTomaszczyk \& M. Thelen (Eds.), Meaning in Translation (pp.437-454). Frankfurt: Peter Lang.

Martinez, S.M \& Faber, P. (2009). Terminological Competence in Translation. Terminology, 15(1), 88-104.

Miller, J.W \& McKenna, M.C. (2016). World Literacy: How Countries Rank and Why It Matters. New York and London: Routledge.

Otto, B \& Rachman, A. (2016). Indonesia opens more big businesses to foreign investment. http://www.wsj.com/articles/indonesiaopens-more-big-businesses-to-foreign-investment-1455185389 [08/12/2016].

Otto, B \& Sentenna, I.M. (2015) Indonesia makes attracting foreign investment a priority. <http://www/wsj.com/articles/indonesiamakes-attracting-foreign-investment-a-priority-1440676597> [08/12/2016].

Yuniarni, S. (2018) Indonesia had 134 M users in 2017: APJII. <http://jakartaglobe.id/business/indonesia-143m-internet-userts-2017apjii $>[19 / 02 / 2018]$. 